\author{
AUTHORS: \\ Ilze Beukes ${ }^{1}$ \\ Lindy J. Rose ${ }^{1}$ \\ Gordon S. Shephard ${ }^{2}$ \\ Bradley C. Flett ${ }^{3}$ \\ Altus Viljoen ${ }^{1}$
}

\section{AFFILIATIONS:}

'Department of Plant Pathology,

Stellenbosch University,

Stellenbosch, South Africa

Institute of Biomedical and

Microbial Biotechnology,

Cape Peninsula University

of Technology, Cape Town,

South Africa

${ }^{3}$ Grain Crops Institute,

Agricultural Research Council,

Potchefstroom, South Africa

\section{CORRESPONDENCE TO:}

Lindy Rose

\section{EMAIL:}

lindym@sun.ac.za

\section{DATES:}

Received: 20 Apr. 2016

Revised: 23 Sep. 2016

Accepted: 30 Sep. 2016

\section{KEYWORDS:}

cereals; food safety; fungal contamination; mycotoxins; phytopathology

\section{HOW TO CITE:}

Beukes I, Rose LJ, Shephard

GS, Flett BC, Viljoen A.

Mycotoxigenic Fusarium species

associated with grain crops

in South Africa - A review.

S Afr J Sci. 2017;113(3/4),

Art. \#2016-0121, 12 pages.

http://dx.doi.org/10.17159/

sajs.2017/20160121

\section{ARTICLE INCLUDES:}

$\times$ Supplementary material

$\times$ Data set

\section{FUNDING:}

National Research Foundation (South Africa); The Maize Trust; Winter Cereal Trust

(C) 2017. The Author(s). Published under a Creative Commons Attribution Licence.

\title{
Mycotoxigenic Fusarium species associated with grain crops in South Africa - A review
}

\begin{abstract}
Cereal grains include some of the most important crops grown in South Africa and play a major role in the local economy. Maize, wheat and sorghum are extensively consumed by humans and farm animals, and are also utilised in industrial processes. Grain crops that are grown commercially contribute up to $33 \%$ of the country's total gross agricultural production, whereas subsistence farmers grow grains mainly to sustain their families. In rural communities an average intake of maize grain of more than $300 \mathrm{~g}$ dry weight per person per day is not uncommon. The production of grains is often constrained by pests and diseases that may reduce their yields and quality. In South Africa, 33 mycotoxin-producing Fusarium species have been associated with grain crops. Mycotoxins, such as fumonisins and deoxynivalenol, have been found in levels exceeding the maximum levels imposed by the US Food and Drug Administration and the European Union and therefore pose a serious public health concern. We provide an extensive overview of mycotoxigenic Fusarium species associated with grain crops in South Africa, with particular reference to maize, wheat and sorghum.

\section{Significance:}

- Mycotoxigenic Fusarium species negatively affect the most important staple food crops grown in South Africa.

- Mycotoxin contamination has a direct impact on food safety and security.

- The genus Fusarium includes some of the most important mycotoxin-producing species.
\end{abstract}

\section{Introduction}

Grain crops grown in South Africa contribute between 25\% and 33\% of South Africa's total gross agricultural production. ${ }^{1,2}$ The most commonly cultivated grain crops include maize (Zea mays L.), wheat (Triticum aestivum L.), barley (Hordeum vulgare L.), sorghum (Sorghum bicolor L.), oats (Avena sativa L.), millet (Pennisetum glaucum L.) and rye (Secale cereal L.). Of these, maize is considered the most important and wheat the second most important. ${ }^{2,3}$ The grains are utilised for food and livestock feed and, to a lesser extent, for malting purposes and bioethanol production. ${ }^{1,2}$ Grains constitute the major portion of the total calorie intake of South Africans, across all age groups. The average consumption of maize by people older than 10 years varies from $762 \mathrm{~g}$ to $848 \mathrm{~g}$ cooked weight per person per day. ${ }^{4}$

The production of grain crops in South Africa is constrained by various abiotic and biotic stresses. Drought, nutrient deficiency, insect damage and diseases all cause a reduction in yield and grain quality. ${ }^{5,6}$ One of the more important biotic stresses affecting maize, wheat and sorghum grain in the country involves the fungal genus Fusarium. The Fusarium sp. most commonly associated with these three grain crops is $F$. graminearum sensu lato (s.I.) Schwabe, also referred to as the Fusarium graminearum species complex. ${ }^{7-10}$ Other Fusarium species affecting maize grain in South Africa include F. verticillioides (Sacc.) Nirenberg (syn. F. moniliforme Sheldon) and $F$. subglutinans (Wollenweber \& Reinking) Nelson, Toussoun \& Marasas, with F. proliferatum (Matsushima) Nirenberg occurring less frequently. ${ }^{8,11,12}$ Fusarium verticillioides is also associated with grain mould of sorghum in South Africa. ${ }^{9,13}$ Additional Fusarium species associated with sorghum include $F$. thapsinum Klittich, Leslie, Nelson \& Marasas; F. andiyazi Marasas, Rheeder, Lamprecht, Zeller \& Leslie; F. nygamai Burgess \& Trimboli; and F. pseudonygamai 0'Donnell \& Nirenberg. ${ }^{13}$ Fusarium head blight of wheat is associated with several species including F. culmorum (W.G. Smith) Sacc., F. cerealis (Cooke) Sacc. (syn. F. crookwellense Burgess, Nelson \& Toussoun) and $F$. avenaceum (Fries) Saccardo. ${ }^{10}$

Infection of grain by Fusarium spp. does not only result in reduced yield and grain quality, but could lead to food safety concerns. Most Fusarium species produce one or more toxic secondary metabolites, commonly known as mycotoxins, in the grain. ${ }^{14} \mathrm{~F}$. graminearum s.l. produces type B trichothecenes (TCT-B) such as deoxynivalenol (DON) and nivalenol (NIV). Another important group of mycotoxins, the fumonisins (FUM), are produced by several Fusarium species (Table 1). Both F. verticillioides and F. proliferatum have been associated with the production of fumonisins in maize and sorghum grains in the country. $8,12,13$

The discovery of fumonisins in South African maize grain by Bezuidenhout et al. ${ }^{15}$ sparked a significant interest in Fusarium-associated mycotoxins in the country and also worldwide. The objective of the current review is to give an overview of the information available on mycotoxigenic Fusarium species associated with grain crops in South Africa. We furthermore provide an outline on the production of the three most important grain food crops in South Africa: maize, wheat and sorghum. 
Table 1: $\quad$ Mycotoxigenic Fusarium species associated with South African grain crops

\begin{tabular}{|c|c|c|c|c|}
\hline Species & South African grain host & References & $\begin{array}{l}\text { Mycotoxins associated with } \\
\text { fungal species }\end{array}$ & References \\
\hline Fusarium acuminatum & Barley, oats, sorghum, wheat & $25,140,141$ & BEA, DON, HT-2, MON, T-2 & $14,140-143$ \\
\hline F. andiyazi & Sorghum & 13,33 & FUM & 11 \\
\hline F. anthophilum & Rice & 144 & BEA, FUM, MON & 45,145 \\
\hline F. avenaceum & Barley, oats, sorghum, wheat & $7,10,52,146$ & BEA, FusaC, MON & $14,147,148$ \\
\hline F. brachygibbosum & Wheat & 10 & Unconfirmed & 149 \\
\hline F. cerealis (syn: F. crookwellense) & Wheat & 10 & DON, NIV, FX, ZEA & 14,150 \\
\hline F. chlamydosporum & Amaranth, maize, sorghum, wheat & $10,49,52,151$ & HT-2, MON, T-2 & 45,152 \\
\hline F. culmorum & Barley, wheat & 7,10 & $\begin{array}{l}\text { AcDON, DON, FX, MON, NIV, } \\
\text { T-2, ZEA }\end{array}$ & $14,148,153-155$ \\
\hline F. dimerum & Maize & 49 & & \\
\hline F. fujikuroi & Wheat & 10 & BEA, FUM, MON & $11,26,156$ \\
\hline F. globosum & Maize & 157 & BEA, FUM & 158,159 \\
\hline F. incarnatum-equiseti species complex & Amaranth, maize, sorghum, wheat & $10,48,52,151$ & BEA, DON, MON, NIV, ZEA & $14,45,140,143,160$ \\
\hline F. merismoides & Sorghum & 52 & ENN & 161 \\
\hline F. napiforme & Millet, sorghum & 32 & FUM, MON & 156,162 \\
\hline F. nygamai & Millet, sorghum & 13,53 & BEA, FUM, MON & $45,156,163$ \\
\hline F. oxysporum & Barley, maize, sorghum, wheat & $10,140,164$ & BEA, FA, FUM, MON, ZEA & $142,165,166$ \\
\hline F. poae & Barley, maize, wheat & $7,10,35,49$ & BEA, Fx, HT-2, NIV, T-2 & $14,27,45,148$ \\
\hline F. proliferatum & Maize & 12 & BEA, FUM, MON & $167-169$ \\
\hline F. pseudograminearum & Ryegrass, wheat & 10,103 & AcDON, DON, Fx, NIV, ZEA & 170,171 \\
\hline F. pseudonygamai & Sorghum & 13 & FUM, MON & $11,13,172$ \\
\hline F. semitectum & Sorghum & 52 & BEA, DON, MON, NIV, ZEA & $46,140,173$ \\
\hline F. solani species complex & Maize, sorghum, wheat & $10,49,52$ & DON, FUM, T-2, ZEA & 47,51 (unconfirmed) \\
\hline F. subglutinans & Maize, sorghum & 8,52 & BEA, FA, FUM, MON & $14,173-177$ \\
\hline F. thapsinum & Sorghum & 13 & FA, FUM, MON & 178,179 \\
\hline F. temperatum & Maize & 180 & BEA, FUM, MON & 181 \\
\hline F. tricinctum species complex & Wheat & 10 & BEA, T-2, ENN, MON & $14,27,148,182$ \\
\hline F. verticillioides (syn: F. moniliforme) & Maize, rice, sorghum & $8,13,146$ & BEA, FusaC, FUM, MON & $80,183,184$ \\
\hline F. graminearum species complex: & Amaranth & 151 & AcDON,DON, Fx, NIV, T-2, ZEA & 45,50 \\
\hline F. acaciae-mearnsii & Wheat, sorghum & 7,9 & 3-ADON, NIV & 185 \\
\hline F. boothii & Barley, maize, wheat & 7 & 15-ADON & 185 \\
\hline F. brasilicum & Wheat & 7 & 3-ADON, NIV & 185 \\
\hline F. cortaderiae & Wheat, sorghum & 7,9 & 3-ADON, NIV & 185 \\
\hline F. graminearum & Barley, maize (roots), wheat & 7,21 & 3-ADON, 15-ADON, NIV & 185 \\
\hline F. meridionale & Maize (roots), sorghum, wheat & $7,9,21$ & NIV & 185 \\
\hline
\end{tabular}

BEA, beauvericin; DON, deoxynivalenol; HT-2, HT-2 toxin; MON, moniliformin; T-2, T-2 toxin; FUM, fumonisins; FusaC, fusarin C; NIV, nivalenol; Fx, fusarenon-X; ZEA, zearalenone; ACDON, acetyldeoxynivalenol; ENN, enniatins; FA, fusaric acid; 15-ADON, 15-acetyldeoxynivalenol; 3-ADON, 3-acetyldeoxynivalenol 


\section{Grain crops in South Africa \\ Maize}

Maize forms the main staple food for the majority of South Africans, and constitutes a major component of animal feed. In 2014/2015, approximately $56 \%$ of the total area under maize cultivation (2 656500 ha) comprised white maize, mainly used for human consumption, and $44 \%$ yellow maize, mostly used for animal feed. ${ }^{2}$ The maize industry, therefore, is an important contributor to the economy of South Africa, both as an employer and generator of income. ${ }^{1}$ In addition to its use as food and feed, maize is utilised in the manufacturing of paper, paint, textiles, adhesives, biodiesel, medicine and food.

Advances in maize cultivation practices - such as improved cultivars, effective crop rotation and enhancements in fertilisation and pesticide programmes - have steadily improved the yield per hectare. Whereas the total area harvested in South Africa has decreased from 4118000 ha in 1960 to 2656500 ha in 2014, yield has increased by 8225000 metric tons (Figure 1a). ${ }^{2,16}$ The increase in production has ensured that the importation of maize has been minimised, and any surplus can be exported (Figure 1a), thus contributing towards generating foreign currency. The Free State (43\%), North West $(20 \%)$ and Mpumalanga (19.5\%) Provinces of South Africa were the main production areas during the 2013/2014 production season for total white and yellow maize harvested. ${ }^{2}$ Maize in South Africa is cultivated during the summer months with ideal planting times in November and December.

Maize production systems in South Africa can vary from resource-poor subsistence farming to small-scale and intensive commercial farming. ${ }^{12,17}$ Chambers and Ghildyal ${ }^{18}$ defined a resource-poor farm family as 'one whose resources of land, water, labour and capital do not permit a decent and secure family livelihood'. The Merriam-Webster online dictionary ${ }^{19}$ defines subsistence farming as: 'Farming or a system of farming that provides all or almost all the goods required by the farm family usually without any significant surplus for sale.' The average yield per hectare recorded from 2008 to 2012 for non-commercial farmers was a meagre 1.3 tons/ha, while commercial farmers produced an average of 4.6 tons $/ \mathrm{ha}^{2}{ }^{2}$

Diseases caused by fungal pathogens - aggravated by the use of inferior seed, monoculture and retaining crop residues - lead to reduced yields and lower grain quality. ${ }^{12} \mathrm{~A}$ survey by Ncube et al. ${ }^{12}$ during two production seasons determined that $F$. verticillioides was the most common Fusarium species associated with maize grain produced in a subsistence farming system, followed by $F$. subglutinans and $F$. proliferatum. Maize grain infected with these species was also contaminated with FUM, often at levels much higher than the maximum levels set by the US Food and Drug Administration (FDA) and the European Union (EU). A maize crop quality survey of commercially produced maize is performed annually by the Southern African Grain Laboratory (SAGL) with the financial support of The Maize Trust. Despite the general good quality of commercial maize, high levels of some mycotoxins can be found when weather or other conditions are favourable for fungal infection. Subsequently, mycotoxin contamination levels, in excess of the maximum levels allowed by the EU for maize intended for direct human consumption, have been found in commercially produced maize. ${ }^{8,17,20} \mathrm{~A}$ 2-year survey of two susceptible maize cultivars, collected at 14 localities across South Africa, found a maximum total FUM level of $16717 \mu \mathrm{g} / \mathrm{kg}$, with an average of $2542 \mu \mathrm{g} / \mathrm{kg}$ and DON levels as high as $4731 \mu \mathrm{g} / \mathrm{kg}$ (average of $1031 \mu \mathrm{g} / \mathrm{kg}$ ). Beauvericin (BEA) was recorded at a maximum level of $1507 \mu \mathrm{g} / \mathrm{kg}$ (average of $506 \mu \mathrm{g} / \mathrm{kg}$ ) and moniliformin (MON) at a maximum of $1530 \mu \mathrm{g} / \mathrm{kg}$ and an average of 604 $\mu \mathrm{g} / \mathrm{kg} .{ }^{8}$ Zearalenone (ZEA) has also been sporadically detected in South African maize. During the $2011 / 2012$ season, only two samples analysed by SAGL tested positive. However, with an average of $249 \mu \mathrm{g} / \mathrm{kg}$, they exceeded the maximum level of $100 \mu \mathrm{g} / \mathrm{kg}$ allowed by the EU. ${ }^{20}$ The occurrence of these mycotoxins could be attributed to the presence of $F$. verticillioides, $F$ graminearum s.I. and $F$. subglutinans. The presence of high mycotoxin levels in commercial maize could possibly be attributed to the fact that commercial farmers still consider yield, not disease resistance, the number one criteria when deciding on a hybrid to plant. Fusarium spp. do not only cause ear rot, but can furthermore cause root, crown and stalk rot of maize, thereby causing additional yield losses. ${ }^{21}$

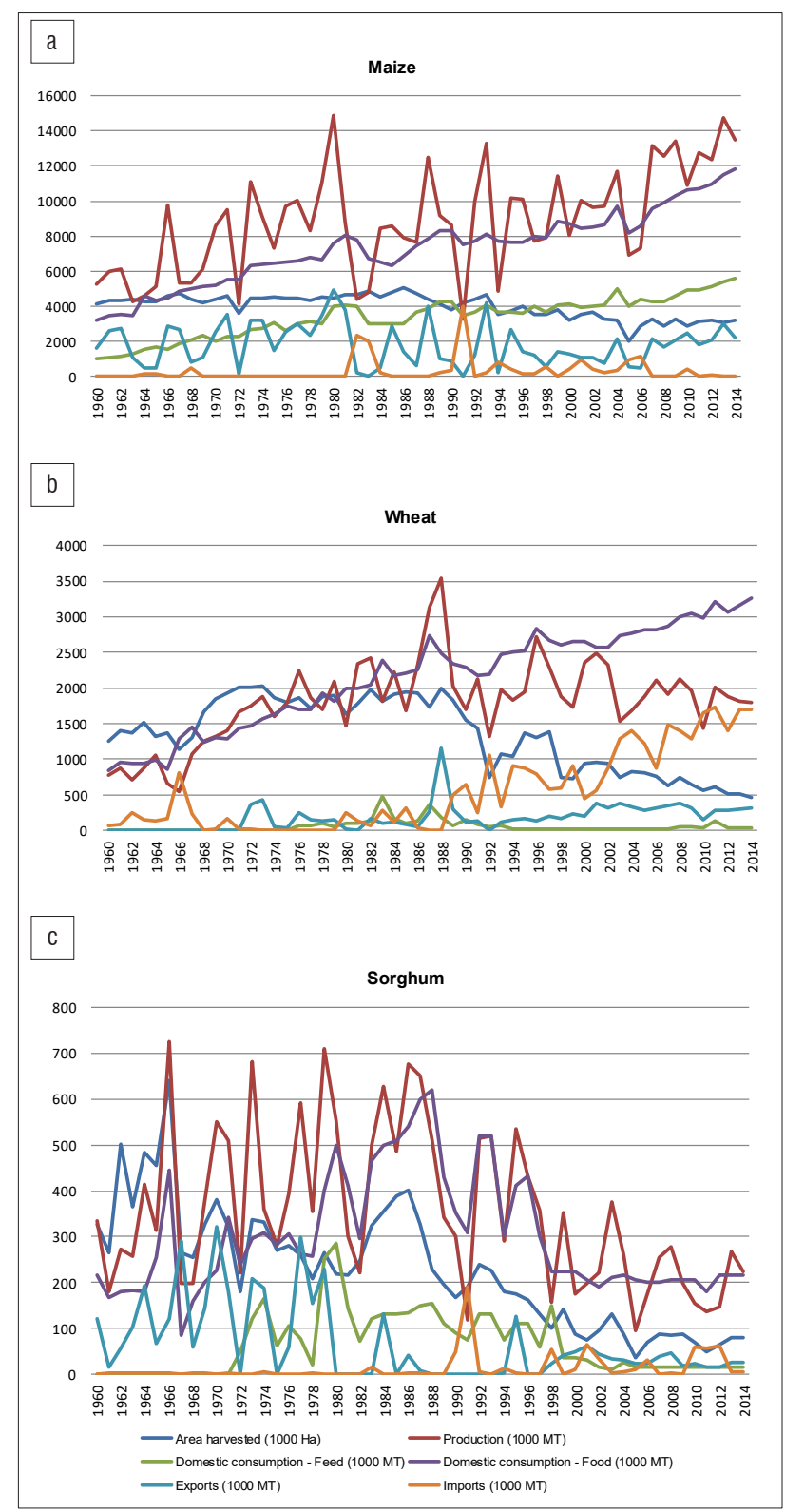

Values used to generate these graphs were obtained from: GrainSA2 and the US Department of Agriculture ${ }^{16}$

Figure 1: Cultivation, usage and trade in South Africa between 1960 and 2014 of (a) maize, (b) wheat and (c) sorghum.

\section{Wheat}

Wheat is the second most important grain crop produced in South Africa and is also regarded as an important staple food. It serves as the second main provider of energy in the national diet after maize meal, even though more money is spent on bread annually (ZAR6.7 billion in 2000) than on maize food products (ZAR6.2 billion in 2000). ${ }^{22}$ The majority of wheat cultivated in South Africa is bread wheat, with minor quantities of durum wheat produced for the production of pasta. Wheat is primarily used for human consumption (bread, biscuits, breakfast cereals, rusks), while the balance is used as seed for re-planting. Poorer quality wheat is marketed as animal feed and other non-food industrial uses such as the production of alcohol for ethanol, absorbing agents for disposable diapers, adhesives and starch on coatings. ${ }^{23}$ Approximately 3900 commercial wheat farmers provide job opportunities to almost 28000 people. $^{24}$

Wheat production in South Africa can be divided into two different cultivation systems, each with their own adapted wheat varieties. In summer-rainfall areas, wheat is mostly cultivated under irrigation, and 
planted between mid-May to the end of July (Northern Cape, Free State, KwaZulu-Natal). In the Western Cape, a winter-rainfall area, wheat is mostly planted under dryland conditions between mid-April and midJune. About $600 \mathrm{~mm}$ water per year is required for wheat cultivation and, in dry areas where zero tillage or minimum tillage are practised, stubble mulching is recommended for moisture conservation. ${ }^{23}$

The main wheat production areas in South Africa during the 2013/2014 season were the Western Cape (50\%), Northern Cape (16\%) and Free State $(15 \%)$. Wheat is predominantly produced by commercial farmers with negligible amounts produced by small-scale and subsistence farmers, mainly because of high input costs and low yields, which results in smaller profit margins. Although the yield per hectare of wheat has shown a steady increase over the past 10 years (2.02 tons/ha in 2004 to 3.73 tons/ha in 2014) ${ }^{2}$, the area harvested has decreased at a higher rate than the increase in yield could support, resulting in an overall reduction in production (Figure 1b). Lower production has led to an increase in the importation of wheat into South Africa to accommodate the drastic increase in domestic consumption (Figure 1b). Production of wheat in South Africa is constrained by several factors. Input costs have increased because of substantial increases in the cost of fertilisers and fuel, competitive international wheat prices and poor climatic conditions, amongst others. ${ }^{23}$ Fertiliser costs in the Swartland wheat-producing area of the Western Cape can be as much as 30\% of the total input cost and weeds may limit grain yields by approximately $20 \%$ annually.

Wheat is susceptible to a range of insect pests and diseases caused by plant pathogenic viruses, bacteria and fungi. ${ }^{5-7,10}$ Several Fusarium species are associated with root rot, crown rot and head blight of wheat in South Africa, including F. avenaceum, F. brachygibbosum Padwick, F. cerealis, F. chlamydosporum Wollenweber \& Reinking, F. culmorum, F. graminearum S.I., F. incarnatum-equiseti (syn. F. equiseti (Corda) Saccardo), F. lunulosporum Gerlach, F. oxysporum Schlechtendahl emend. Snyder \& Hansen, F. poae (Peck) Wollenweber, F. pseudograminearum Aoki \& O'Donnell, F. solani (Martius) Appel \& Wollenweber emend. Snyder \& Hansen and $F$. tricinctum (Corda) Saccardo.,10,25 The presence of some of these species may result in the contamination of the infected grain with mycotoxins such as DON, ZEA, BEA and MON. 14,26,27

\section{Sorghum}

Sorghum is the fourth most important grain crop produced in South Africa after maize, wheat and barley, and the third most important food grain crop. ${ }^{2,28}$ Barley is mostly used for malting purposes in the production of beer, and is not considered a major food crop in South Africa. Sorghum is indigenous to Africa and is considered a staple food in many rural communities in South Africa. Approximately $90 \%$ of commercially grown grain sorghum is used for human consumption in the form of beverages and food (e.g. malt and sorghum meal), while the remainder is used as animal feed. ${ }^{28,29}$ Industrial uses of sorghum include wallboards, biodegradable packaging materials and the production of ethanol. The brewing industry is the main consumer of sorghum, and about $55 \%$ of the total domestic produce is used for the manufacturing of traditional African sorghum beer. Sorghum flour competes directly with maize meal as a breakfast cereal or as soured porridge, known as 'mabele'. ${ }^{28}$ However, mabele has been found to have better nutritional value $(9.7 \%$ protein, $1.6 \%$ fat) when compared to super maize meal (7.4\% protein, $1.0 \%$ fat). In South Africa, sorghum cultivars are divided into three classes: Class GM includes sweet sorghum with a low tannin content, which is especially suitable for malting and milling purposes; Class GL includes sweet sorghum with a low tannin content, which is especially suitable for milling and animal feed purposes; and Class GH includes bitter sorghum with a high tannin content (bird resistant), which is used for industrial malting. ${ }^{28}$

The area under sorghum cultivation and the total production of sorghum in South Africa has been on a decline since 1986 (Figure 1c). 2,16 While maize and wheat increased in yield per hectare (Figure 1a,b), the same was not observed for sorghum (Figure 1c), for which the yield per hectare has remained mostly unchanged since 1995, fluctuating only with climatic changes. ${ }^{2}$ This observation could be explained by the limited amount of research and development funds available to the sorghum industry, which is relatively small when compared to other major grain crops. A total of only 903000 tons sorghum was produced in the 5 years from 2009 to 2014, in comparison to 8.9 million tons of wheat and 61 million tons of maize produced during the same period. ${ }^{2}$

Sorghum is planted from mid-October to mid-December in South Africa. ${ }^{29}$ The Limpopo Province is the main sorghum-producing province, with limited production in other provinces such as Mpumalanga, North West, Northern Cape, Eastern Cape, KwaZulu-Natal and the Free State. ${ }^{30}$ As with maize, sorghum farming systems vary from subsistence to intensive commercial farming, depending on farm sizes, production and marketing methods..$^{30}$ Subsistence farmers consume most of their products without measuring the area under production and yield. The average sorghum yield on smallholder farms is estimated to be 0.8 tons/ $\mathrm{ha}^{30}$, significantly lower than the 2.4 tons/ha produced on commercial farms ${ }^{2}$. The lower yield per hectare for subsistence farmers can be attributed to insufficient fertiliser and pest control programmes as well as soil cultivation and crop rotation practices, amongst others. These factors furthermore favour disease development by fungal pathogens, thus increasing the possibility of mycotoxin contamination.

Fusarium grain mould is a very important biological constraint to sorghum production worldwide, while Fusarium stalk and root rot may result in lodging, causing decreased yields..$^{13,31-33}$ Several mycotoxinproducing Fusarium species have been isolated from sorghum grain in South Africa. F. andiyazi, F. nygamai, F. thapsinum and $F$. verticillioides ${ }^{13}$ are known FUM producers, while species within $F$. graminearum s.l. are TCT-B and ZEA producers ${ }^{9}$.

The high consumption levels of up to $500 \mathrm{~g} /$ person/day $^{34}$ of inferior quality maize and sorghum by subsistence farmers pose a considerable threat to human health. Case studies have shown that the incidence of oesophageal cancer in areas where grain with high levels of FUM contamination is consumed is much higher than in other populations where FUM-contaminated food is not a staple. ${ }^{35,36}$

\section{Mycotoxigenic Fusarium species affecting South African grains}

The mycotoxin-producing Fusarium species first described from grain in South Africa was F. culmorum, which was isolated from the stems and roots of wheat grown near Stellenbosch, Western Cape, in the 1930s. ${ }^{37}$ By the end of 1985, a total of 27 Fusarium species, either toxigenic or non-toxigenic, had been reported from a broad range of hosts in South Africa. ${ }^{32,38}$ To date, 33 mycotoxigenic Fusarium species have been associated with local grain crops (Table 1). These species include $F$. verticillioides, $F$. proliferatum and $F$. subglutinans, which are commonly associated with Fusarium ear rot (FER) of maize, and $F$. graminearum s.I. that causes Gibberella ear rot of maize, Fusarium head blight (FHB) of wheat and barley and grain mould of sorghum (Table 1). Certain Fusarium species are associated with FER, FHB and Fusarium crown rot under specific climatic conditions. For instance, FHB of wheat is caused by $F$. avenaceum, $F$. culmorum and $F$. poae in the cooler regions, whereas $F$. graminearum is predominant in the warmer regions worldwide. ${ }^{39}$ In South African maize, the FER pathogen $F$. verticillioides predominates in the warmer dry areas, while $F$. subglutinans is abundant in cooler areas. The Gibberella ear rot pathogen, $F$. graminearum s.l., is most prevalent in intermediate climate areas. ${ }^{40}$ Mycotoxin-producing species such as F. polyphialidicum Marasas, Nelson, Toussoun \& van Wyk and $F$. sacchari (E. J. Butler) W. Gams are known to occur on grain crops elsewhere in the world, but have, to date, not been found on South African grains. These two species have, however, been found in soil debris and sugarcane, respectively, in South Africa. ${ }^{41,42}$

FuM-producing Fusarium species, such as $F$. verticillioides and $F$. proliferatum, are often associated with maize and sorghum in South Africa (Table 1). Maize samples collected from 2001 until 2013 tested positive for FUM, sometimes at levels in excess of the maximum levels allowed by the EU. ${ }^{20}$ More FUM and FUM-producing Fusarium species were found in maize grain produced commercially in warmer production areas of the Northern Cape, North West and Free State Provinces ${ }^{17}$ than in the cooler production regions. Although FUM 
contamination of small grain cereals has been reported ${ }^{43}$, this mycotoxin has not been found in wheat and barley in South Africa when employing a multi-mycotoxin screening method using ultra-performance liquid chromatography mass-mass spectrometry ${ }^{44}$. ZEA and TCT-Bs, however, have been found in both maize and wheat in the country, ${ }^{20,44}$ but at higher levels and more frequently in maize than in wheat. The TCT-Bs and ZEA are primarily produced by Fusarium species within F. graminearum S.l. ${ }^{45,46}$, and are commonly associated with Gibberella ear rot of maize, FHB of wheat and grain mould of sorghum ${ }^{7-10}$.

The highly toxic mycotoxin, T-2 toxin, has until recently not been recorded in South Africa. T-2 toxin is most commonly produced by $F$. sporotrichioides, a fungus well-adapted to survive in colder countries ${ }^{47}$ Some T-2-producing Fusarium species, such as F. poae and $F$. chlamydosporum (Table 1), have periodically been isolated from wheat with FHB and maize with FER symptoms in South Africa. ${ }^{35,48,49}$ The presence of T-2 toxin in local maize grain, recently reported by the $\mathrm{SAGL}^{20}$, as well as its association with $F$. verticillioides and F. graminearum ${ }^{50,51}$, requires further investigation.

Information on mycotoxin contamination of oats, sorghum and millet in South Africa is limited. Sorghum is affected by Fusarium species ${ }^{32,33,52,53}$ that produce BEA, FUM, MON, TCT-B and ZEA, such as F. avenaceum, $F$. chlamydosporum, $F$. nygamai and the $F$. solani species complex (Table 1). Some of the same Fusarium species have also been associated with oats, millet or other less important grains such as amaranth. F. verticillioides, a common producer of FUM, also produces mycotoxins of lesser importance such as BEA, Fusarin C and MON (Table 1). The lower toxicity of these mycotoxins, and the relative complexity of multi-mycotoxin analysis ${ }^{54}$ limits the amount of data available on their occurrence in South African grains.

\section{Role of mycotoxins in plant disease development}

The role of mycotoxins in the interaction of fungi with plants is not always clearly understood. Some have, however, been shown to benefit the fungus. ${ }^{55,56}$ The TCT-Bs, for instance, are phytotoxic and act as virulence factors on sensitive hosts, allowing the fungus to progress in plant tissue. ${ }^{57}$ This effect was demonstrated by non-TCT-producing $F$. graminearum mutants that were pathogenic, yet caused less disease in maize than did wild-type TCT-producing isolates. ${ }^{58,59}$ The virulence of $F$. graminearum and F. culmorum was also closely correlated with their DON and NIV deposition in wheat grain.$^{56}$ Adams and Hart ${ }^{60}$, in contrast, reported that DON was not a virulence or pathogenicity factor for $F$. graminearum on maize, following virulence trials with non-toxic protoplast fusion $F$. graminearum strains.

FUM has been shown to be phytotoxic to maize seedlings, but its role in phytotoxicity, virulence and pathogenicity is unclear. The phytotoxicity of FUM was demonstrated by Williams et al. ${ }^{61}$ and Arias et al. ${ }^{62}$ who reported that FUM had a direct inhibitory effect on root growth, root hair development and other functions within the plant, whereas van Asch et al. ${ }^{63}$ reported the mycotoxin to be phytotoxic to maize callus in culture. Symptoms were further induced when seedlings were watered with high concentrations of FUM in the absence of the pathogen. ${ }^{62}$ Glenn et al..$^{64}$ demonstrated that FUM production by $F$. verticillioides is necessary for the development of foliar disease symptoms on maize seedlings. Desjardins et al. ${ }^{65}$ acknowledged that FUM could play a role in virulence, but argued that it is not essential for pathogenicity to maize seedlings. These authors compared the offspring of a fum $1^{+}$field strain of $F$. verticillioides with a high degree of virulence and that of a fum 1 - field strain. They found that progeny with high levels of virulence were associated with FUM production, while highly virulent FUM-nonproducing progeny were not observed. However, a highly virulent FUMnon-producing wild-type isolate was also identified, indicating FUM is not required for virulence. FUM non-producing mutants of $F$. verticillioides, generated by the disruption of the FUM5 gene, have been as virulent on maize ears as their wild-type predecessor strains. ${ }^{59}$

Mycotoxins could also be involved in reproduction, fungal development and the colonisation of plant tissue. Disruption of a cyclin-like (C-type) gene, FCC1, resulted in reduced FUM $B_{1}$ synthesis and sporulation. ${ }^{66}$ FUM is also believed to provide a competitive advantage to the fungus as it inhibits the mycelial growth of other fungal species in vitro. ${ }^{67}$ The oestrogenic mycotoxin ZEA enhances perithecial production in F. graminearum, therefore the sexual development of the fungus is suppressed when ZEA synthesis is inhibited..$^{55}$

\section{Impact of mycotoxins on human and animal health}

The mycotoxins most commonly found in South African grains include DON, FUM and ZEA. ${ }^{8,12,20}$ DON, also known as vomitoxin because of its strong emetic effects after consumption, is one of the most widely distributed TCTs found in grain. When consumed by livestock, DON can lead to food refusal, vomiting, decreased weight gain and less effective

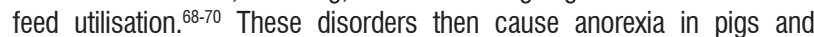
other monogastric animals. Ruminants and poultry appear to be resistant to DON. ${ }^{71}$ In humans, ingestion of DON-contaminated food has been associated with nausea, vomiting and diarrhoea. ${ }^{72}$ Outbreaks of acute DONassociated gastrointestinal illness in humans have been reported in China in $1984 / 1985$ and in India in 1987. ${ }^{73}$ The ingestion of NIV, which is considered more toxigenic than DON, has resulted in decreased feed consumption, lower feed conversion efficacy and decreased liver weights when fed to chickens. ${ }^{74,75}$ NIV and NIV-producing F. graminearum s.l. species have, however, been less frequently associated with South African grains. ${ }^{7,8}$

High levels of FUM in maize grain has been associated with leukoencephalomalacia. Leukoencephalomalacia is a fatal condition that causes the softening of brain tissue as a result of vascular insufficiency or degenerative changes in horses and rabbits. ${ }^{76-78}$ FUM has also resulted in fatal pulmonary oedema in pigs and high tumour formation incidences in rats. ${ }^{79-81}$ FUM was discovered following the association of $F$. verticillioides-contaminated maize grain with a high incidence of oesophageal cancer in the Transkei region (Eastern Cape Province) of South Africa. $35,80,82,83$ Since then, the mycotoxin has also been associated with human oesophageal cancer in China and Italy and with prenatal birth defects and higher HIV transmission rates. ${ }^{84,85}$

ZEA is one of the most widely distributed Fusarium mycotoxins globally. Despite its relatively low acute toxicity, ZEA is biologically potent ${ }^{86}$ and may cause reproductive disorders in farm animals ${ }^{45,86,87}$. ZEA-containing feed and fungal cultures fed to chickens and turkeys have resulted in significantly reduced egg production. ${ }^{88,89}$ In humans, ZEA has been linked to hypoestrogenic syndromes and is believed to be an eliciting factor for advanced puberty development in girls. ${ }^{90,91}$ The potential of ZEA to stimulate the growth of human breast cancer cells has also been demonstrated in vitro. ${ }^{92}$

The EU and FDA established maximum allowable levels for certain food contaminants, including mycotoxins, with the aim to reduce their presence in foodstuffs to the lowest levels reasonably achievable by means of good manufacturing or agricultural practices. ${ }^{73,93}$ In addition to the USA and countries within the EU, more than 100 other countries have established mycotoxin regulations for at least aflatoxin $B_{1}$, mostly produced by Aspergillus spp., to aid in minimising food safety concerns. ${ }^{94}$ Fewer countries regulate Fusarium mycotoxins, and in South Africa no restrictions for maximum allowable levels of any of the Fusarium-related mycotoxins in food and feed are governed by legislation.

\section{Management of mycotoxigenic Fusarium species}

Good Agricultural Practice is a collective set of international codes of practice which forms part of the Codex Code of General Principles on Food Hygiene. ${ }^{95}$ These codes are concerned with all aspects of primary food production, including environmental protection and sustainability, economics, food safety, food quality and health security. It also complements the Hazard Analysis Critical Control Point food management system designed to limit food safety concerns, including food poisoning by mycotoxins. ${ }^{95,96}$ The Good Agricultural Practice codes recommend practices for primary production of foodstuffs including fruits, vegetables, grains and legumes. Adherence to these codes of good practice does not only impact on food safety locally, but also influences international trade. Great attention should thus be given to these codes when deciding on an integrated disease management strategy to control Fusarium species and their associated mycotoxins in different grains produced in South Africa. 


\section{Pre-harvest control}

Field preparation and cultivation practices play a central role in the management of Fusarium diseases and their associated mycotoxins. ${ }^{95}$ The burial of residue plant material from a previous planting season by deep ploughing can reduce the primary inoculum that causes infections. ${ }^{97}$ This is especially important when crops are affected by the same Fusarium species, such as F. graminearum s.l. on maize, wheat and sorghum grown in rotation. While minimum tillage has significantly decreased stalk rot and increased grain yield of sorghum in South Africa ${ }^{31}$, it also has increased inoculum build-up of mycotoxigenic fungi in maize cropping systems ${ }^{95}$. Crop rotation with legumes, brassicas and potato could also significantly reduce $F$. graminearum s.I. levels..$^{98}$ Limiting plant stress to increase plant vigour by adhering to optimum plant dates, preventing drought stress and the optimal use of fertilisers have reduced Fusarium infection in a number of grain crops. ${ }^{99-101}$ Control of alternative hosts for Fusarium species, which include grasses and weeds, can also reduce unwanted inoculum build-up. 95,102,103

No fungicides are registered for the control of Fusarium grain diseases on maize, wheat or sorghum in South Africa. ${ }^{104}$ Triazole fungicides such as metconazole and tebuconazole, however, have been shown to control FHB and DON contamination in wheat. ${ }^{105}$ Control of mycotoxigenic Fusarium species in maize with fungicides, however, is difficult as ears are covered by tight husks which prevent contact with ear rot pathogens. Field trials in South Africa have reported no significant differences in the colonisation of maize grain by $F$. verticillioides or FUM contamination after application of protective fungicides such as the strobilurins, triazoles and benzimidazoles. ${ }^{106}$ Chemical elicitors also failed to reduce FER and FUM contamination in maize. ${ }^{107}$ As strict regulations on chemical pesticides and fungicide use are implemented to reduce human exposure and prevent environmental pollution, biological control has become more popular. ${ }^{108}$ Non-pathogenic fungal antagonists such as Phoma betae A.B. Frank and Trichoderma spp. Persoon have reduced FHB and DON contamination under greenhouse conditions, but field results were variable and often failed. ${ }^{99,109,110}$ In Ethiopia, $100 \%$ disease suppression of Fusarium root and crown rot of sorghum was reported after application of Bacillus spp. under greenhouse conditions. ${ }^{111}$

Disease resistance is the most proficient and environmentally safe management practice to reduce Fusarium diseases in grain crops. Several quantitative trait loci (QTLs) that underlie resistance to FHB have been mapped in wheat, and can be used for marker-assisted selection. ${ }^{112-114}$ In South Africa, commercial wheat cultivars and breeding lines containing resistance QTLs derived from Sumai 3 lines with low levels of FHB and DON content were identified under field conditions. ${ }^{115}$ The resistance of maize cultivars grown in South Africa to FER and FUM contamination are uncharacterised but resistant maize inbred lines were identified. ${ }^{116}$ These inbred lines could be used as sources of resistance within maize breeding programmes. Mapping studies have previously identified QTLS associated with resistance to FER and FUM contamination in maize. ${ }^{117,118}$ However, studies to identify possible QTLs for resistance to grain mould in sorghum were less frequent, but have shown some success. ${ }^{119-121}$

Unconventional methods to control plant diseases are becoming more common. Maize hybrids genetically modified with crystal (Cry) genes from the bacterium Bacillus thuringiensis, known as Bt-maize, reduced the feeding of stem borers and resulted in lower infection by $F$. verticillioides and $F$. proliferatum and subsequently reduced FUM contamination. ${ }^{122}$ FUM detoxification has also been achieved by genetic modification of maize with a degradative enzyme originating from Exophiala spinifera and Rhinocladiella atrovirens. ${ }^{123}$

\section{Post-harvest control}

FUM and DON levels in grain do not increase significantly when grain is harvested at $<14 \%$ moisture and when optimal moisture and temperature conditions and control of insect pests are maintained during storage. ${ }^{124-126}$ The removal of mouldy, broken and underdeveloped kernels can also significantly lower mycotoxin levels in cereal grains. FUM levels of maize were reduced between $26.2 \%$ and $69.4 \%$ by sieving $(<3 \mathrm{~mm})$, and by $71 \%$ by separating mouldy from healthy kernels of maize produced by subsistence farmers in the former Transkei. ${ }^{127,128}$ An $86 \%$ reduction of FUM was also achieved by the removal of $F$. verticillioidescontaminated maize kernels by flotation in water and sodium chloride, as these were less dense than sound kernels. ${ }^{129}$ The separation of smaller, underdeveloped and shrivelled wheat kernels by means of the Carter dockage tester resulted in a $6-19 \%$ reduction of DON. ${ }^{130}$

Mycotoxins are mostly heat stable; however, the preparation of South African traditional maize porridge through normal household cooking can reduce FUM by $23 \%{ }^{131}$ The washing of barley with distilled water has reduced DON levels by $69 \%$ and ZEA levels by $2 \%$. In maize, DON levels were reduced by $65 \%$ and ZEA levels by $61 \%$. A further reduction in DON and ZEA was achieved by using $1 \mathrm{M}$ sodium carbonate solution for the first wash. ${ }^{132}$ The conversion of mycotoxins into non-toxic products can also be achieved through physical or chemical processes. Chemical degradation of DON has been achieved by ammonia, calcium hydroxide, chlorine, hydrochloric acid, ozone, sodium bisulfite, and sodium hydroxide. ${ }^{133-136}$ However, the large-scale application of these methods are hampered by costs, safety concerns and the negative impact on grain quality. ${ }^{137}$ Biological detoxification, defined as the enzymatic degradation of mycotoxins or modification of their structure that leads to less toxic products, offers an alternative method to reduce the mycotoxin content in food and feed products. ${ }^{138}$

\section{Discussion}

Mycotoxigenic Fusarium species negatively affect the most important staple food crops grown in South Africa by reducing their yield and quality, and by contaminating the grain with harmful mycotoxins. These effects pose a serious threat to food safety and security for a rapidly expanding population. Efforts to manage harmful Fusarium species and their associated mycotoxins, both in commercial and subsistence farming systems, should therefore be made to sustain food production, to reduce health risks to humans and other animals, and to safeguard competitive international trade. A first step in achieving this aim could be the introduction of maximum levels for Fusarium mycotoxins in South African food and feed - a directive which has been conspicuously overlooked by the Departments of Health and Agriculture in the country.

A policy brief was compiled in 2009 to $^{139}$ :

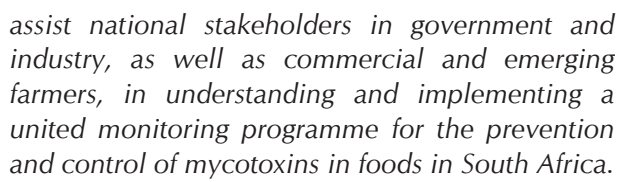

This brief recommended that DON and FUM be added to existing South African regulations in order to align with the guidelines adopted by most other mycotoxin-regulating countries..$^{94,139}$ Recently, South Africa has amended regulations regarding the tolerances for fungus-produced toxins in foodstuffs by limiting DON in grains to 2000 and $1000 \mu \mathrm{g} / \mathrm{kg}$ before and after processing, respectively. Maize grain, intended for further processing, is limited to $4000 \mu \mathrm{g} / \mathrm{kg}$ FUM while processed products, ready for human consumption, may not contain more than $2000 \mu \mathrm{g} / \mathrm{kg}$ of FUM. ${ }^{186}$ Maximum levels for South Africa should be established by determining the general toxicity, haematotoxicity and immunotoxicity of the different mycotoxins as well as considering consumption levels of grain in the country. Incidences of mycotoxicoses, such as the outbreaks of DON-associated acute gastrointestinal illness in humans in China in 1984/1985 and in India in $1987^{73}$, should also be taken into consideration. The biggest limiting factors in this undertaking would be the costs involved in an extensive regulation programme of foodstuffs, such as the laboratory analyses and the monitoring of revised mycotoxin legislation by health inspectors.

Health workers should be trained to identify symptoms exhibited by humans and animals in cases of mycotoxicoses. A serious call should be made on government to support mycotoxin research and to implement legislation on the levels of the different toxins present in foodstuff. The high intake of grains, in terms of both portion size and frequency, as staple foods by the majority of South Africans should be considered when determining allowable levels of contamination. Coordinated efforts should furthermore be made to launch public awareness campaigns 
through the distribution of educational information, in a responsible manner, without evoking public fear. These efforts should be particularly focused in subsistence farming communities, in which mycotoxicoses pose a genuine public health threat, as a high incidence of oesophageal cancer in the Transkei region of South Africa has been directly linked to high FUM contamination. ${ }^{82}$

Managing the incidence and severity of mycotoxin contamination in grains, to reduce human and animal health risks and to safeguard competitive international trade, requires continuous efforts to understand and subsequently control the Fusarium species responsible for the production of these mycotoxins. South Africa, with its internationally recognised track record in mycotoxin research, possesses the skills, expertise and motivation to continue to work towards food safety and security for all people.

\section{Acknowledgements}

Mycotoxin research at Stellenbosch University is funded by the Maize Trust, the Winter Cereal Trust and the Technology and Human Resources for Industry Programme (THRIP) of the National Research Foundation of South Africa. We declare no conflict of interest.

\section{Authors' contributions}

I.B. was responsible for the design and content of the work; for the collection, analysis and interpretation of the data; and for drafting the manuscript. A.V. was responsible for the conception and design of the work. L.J.R., G.S.S., B.C.F. and A.V. critically revised the manuscript. All authors approved the final version.

\section{References}

1. South African Department of Agriculture, Forestry and Fisheries. Pocket guide to South Africa 2011/12 [document on the Internet]. c2012 [cited 2015 Feb 24]. Available from: http://www.gcis.gov.za/sites/default/files/docs/ resourcecentre/pocketguide/013_agriculture.pdf

2. GrainSA. Industry reports [homepage on the Internet]. c2015 [cited 2015 Feb 25]. Available from: http://www.grainsa.co.za/pages/industry-reports/ production-reports

3. Goldblatt A. Agriculture: Facts and trends, South Africa [document on the Internet]. c2012 [cited 2015 Mar 30]. Available from: http://awsassets.wwf. org.za/downloads/facts_brochure_mockup_04_b.pdf

4. Nel JH, Steyn NP. Report on South African food consumption studies undertaken amongst different population groups (1983-2000): Average intakes of foods most commonly consumed. Pretoria: Directorate: Food Control, Department of Health; 2002. Available from: http://www.mrc.ac.za/ chronic/foodstudy.pdf

5. Rybicki EP, Pietersen G. Plant virus disease problems in the developing world. Adv Virus Res. 1999;53:127-175. http://dx.doi.org/10.1016/S00653527(08)60346-2

6. Oerke EC. Crop losses to pests. J Agric Sci. 2006;144(1):31-43. http:// dx.doi.org/10.1017/S0021859605005708

7. Boutigny A-L, Ward TJ, Van Coller GJ, Flett B, Lamprecht SC, O'Donnell K, et al. Analysis of the Fusarium graminearum species complex from wheat, barley and maize in South Africa provides evidence of specie-specific differences in host preference. Fungal Genet Biol. 2011;48(9):914-920. http://dx.doi.org/10.1016/j.fgb.2011.05.005

8. Boutigny A-L, Beukes I, Small I, Zuhlke S, Spiteller M, Janse Van Rensburg B, et al. Quantitative detection of Fusarium pathogens and their mycotoxins in South African maize. Plant Pathol. 2012;61(3):522-531. http://dx.doi. org/10.1111/j.1365-3059.2011.02544.x

9. Mavhunga M. Fusarium graminearum mycotoxins associated with grain mould of maize and sorghum in South Africa [MSc dissertation]. Bloemfontein: University of the Free State; 2013.

10. Van Coller GJ, Boutigny A-L, Rose L, Ward TJ, Lamprecht SC, Viljoen A. Fusarium spp. associated with head blight of wheat in South Africa. In: Acta Phytopathologica Sinica. 10th International Congress of Plant Pathology Abstracts; 2013 August 25-30; Beijing, China. Available from: http://www. isppweb.org/abstracts/interno_icpp_2013.pdf
11. Rheeder JP, Marasas WFO, Vismer HF. Production of fumonisin analogs by Fusarium species. Appl Environ Microbiol. 2002;68(5):2101-2105. http:// dx.doi.org/10.1128/AEM.68.5.2101-2105.2002

12. Ncube E, Flett BC, Waalwijk C, Viljoen A. Fusarium spp. and levels of fumonisins in maize produced by subsistence farmers in South Africa. S Afr J Sci. 2011;107(1/2), Art. \#367, 7 pages. http://dx.doi.org/10.4102/sajs. v107i1/2.367

13. Leslie JF, Zeller KA, Lamprecht SC, Rheeder JP, Marasas WFO. Toxicity, pathogenicity, and genetic differentiation of five species of Fusarium from sorghum and millet. Phytopathology. 2005;95(3):275-283. http://dx.doi. org/10.1094/PHYTO-95-0275

14. Bottalico A, Perrone G. Toxigenic Fusarium species and mycotoxins associated with head blight in small-grain cereals in Europe. Eur J Plan Pathol. 2002;108:611-624. http://dx.doi.org/10.1023/A:1020635214971

15. Bezuidenhout SC, Gelderblom WCA, Gorst-Allman CP, Horak RM, Marasas WFO, Spiteller G, et al. Structure elucidation of the fumonisins, mycotoxins from Fusarium moniliforme. J Chem Soc Chem Commun. 1988;11:743-745. http://dx.doi.org/10.1039/C39880000743

16. United States Department of Agriculture (USDA). Indexmundi [database on the Internet]. c2015. [cited 2015 Feb 20]. Available from: http://www. indexmundi.com/agriculture/?country $=$ za\&commodity $=$ corn \&graph $=$ prod uction

17. Janse van Rensburg B, McLaren NW, Schoeman A, Flett BC. Fumonisin producing Fusarium spp. and fumonisin contamination in commercial South African maize. Eur J Plant Pathol. 2015;141(3):491-504. http://dx.doi. org/10.1007/s10658-014-0558-7

18. Chambers R, Ghildyal BP. Agricultural research for resource-poor farmers: The Farmer-First-and-Last Model. Agric Admin. 1985;20:1-30. http://dx.doi. org/10.1016/0309-586X(85)90063-9

19. The Merriam-Webster dictionary [online]. Subsistence farming. [cited 2015 Mar 09]. Available from http://www.merriam-webster.com

20. South African Grain Laboratory. South African maize crop quality repor 2012/2013 [document on the Internet]. c2013 [cited 2015 Mar 24]. Available from: http://www.sagl.co.za/Portals/0/Maize\%20Crop\%202012\%202013/ Maize\%20Crop\%20Quality\%20Report\%202012\%202013.pdf

21. Lamprecht SC, Tewoldemedhin YT, Botha WJ, Calitz FJ. Fusarium graminearum species complex associated with maize crowns and roots in the KwaZulu-Natal province of South Africa. Plant Dis. 2011;95:1153-1158. http://dx.doi.org/10.1094/PDIS-02-11-0083

22. South African Department of Agriculture. Wheat [document on the Internet]. c2006 [cited 2015 Mar 10]. Available from: http://www.nda.agric.za/docs/ FactSheet/Wheat06.pdf

23. South African Department of Agriculture, Forestry and Fisheries. Wheat production guideline [document on the Internet]. c2010 [cited 2015 Mar 11]. Available from: http://www.daff.gov.za/docs/brochures/prodguidewheat.pdf

24. National Chamber of Milling. Strategy document for the South African wheat to bread value chain [document on the Internet]. c2004 [cited $2015 \mathrm{Mar}$ 10]. Available from: https://www.google.co.za/url?sa =t\&rct=j\&q=\&esrc $=$ $\mathrm{s} \&$ source $=$ web $\& \mathrm{~cd}=1 \& \mathrm{cad}=$ rja\&uact $=8 \&$ ved $=0$ ahUKEwiu7db3hfzRAhV J7mMKHcnBCWQQFggYMAA\&url=http\%3A\%2F\%2Fwww.waterberg.gov.za \%2Fdocs\%2Fagriculture\%2Fother\%2FWHEAT\%25252520Strategy\%252525 20(April\%252525202004)\%255B1\%255D.doc\&usg=AFQjCNFrgHBJi85HIJ xF7Uw7gj5bamvxfA\&sig2=DxyhgXuvmuaYMDhqFXkUqA\&bvm=bv.14609 4739 ,d.d2s

25. Van Coller GJ, Sedeman Z, Lamprecht SC, Viljoen A. Fusarium species associated with crown rot of wheat in South Africa. In: 47th Congress of the Southern African Society for Plant Pathology; 2011 January 23-26; Kruger National Park, South Africa. Available from: https://www.researchgate.net/ publication/269699542_Fusarium_species_associated_with_crown_rot of wheat_in_South_Africa

26. Moretti A, Logrieco A, Bottalico A, Ritieni A, Fogliano V, Randazzo G. Diversity in beauvericin and fusaproliferin production by different populations of Gibberella fujikuroi (Fusarium section Liseola). Sydowia. 1996;48:44-56.

27. Thrane U, Adler A, Clasen P-E, Galvano F, Langseth W, Lew H, et al. Diversity in metabolite production by Fusarium langsethiae, Fusarium poae, and Fusarium sporotrichioides. Int J Food Microbiol. 2004:95(3):257-266. http:// dx.doi.org/10.1016/j.ijfoodmicro.2003.12.005 
28. The Sorghum Section 7 Committee. Report on the investigation into the South African sorghum industry. A report by the Sorghum Section 7 Committee appointed by the National Agricultural Marketing Council [document on the Internet]. c2007 [cited 2015 Feb 25]. Available from: http://www.namc.co.za/ upload/section_7_reports/SORGHUM\%20S7\%20FINAL\%20REPORT\%20 03.07.mdi.pdf

29. South African Department of Agriculture. Sorghum production [document on the Internet] c2008. [cited 2015 March 11]. Available from: http://www.nda. agric.za/docs/Infopaks/FieldCrops_Sorghum.pdf

30. South African Department of Agriculture, Forestry and Fisheries. Sorghum production guideline [document on the Internet]. c2010 [cited 2015 Mar 10]. Available from: http://www.nda.agric.za/docs/Brochures/prodGuideSorghum. pdf

31. Flett BC. Crop rotation and tillage effects on yield and the incidence of root and stalk rot in sorghum (Sorghum bicolor). S Afr J Plant Soil. 1996;13:136-138.

32. Marasas WFO, Rabie CJ, Lübben A, Nelson PE, Toussoun TA, Van Wyk PS. Fusarium napiforme, a new species from millet and sorghum in southern Africa. Mycologia. 1987;79(6):910-914. http://dx.doi.org/10.2307/3807697

33. Marasas WFO, Rheeder JP, Lamprecht SC, Zeller KA, Leslie JF. Fusarium andiyazi sp. nov., a new species from sorghum. Mycologia. 2001;93(6):12031210. http://dx.doi.org/10.2307/3761681

34. Shephard GS. Impact of mycotoxins on human health in developing countries. Food Addit Contam. 2008;25(2):146-151. http://dx.doi. org/10.1080/02652030701567442

35. Marasas WFO, Wehner FC, Van Rensburg SJ, Van Schalkwyk DJ. Mycoflora of corn produced in human esophageal cancer areas in Transkei, southern Africa. Phytopathology. 1981;71:792-796. http://dx.doi.org/10.1094/ Phyto-71-792

36. Jaskiewicz K, Marasas WFO, Van der Walt FE. Oesophageal and other main cancer patterns in four districts of Transkei, 1981-1984. S Afr Med J. 1987;72(1):27-30.

37. Doidge EM. The South African fungi and lichens to the end of 1945. Bothalia. 1950;5:1-1094.

38. Marasas WFO, Lamprecht SC, Van Wyk PS, Anelich RY. Bibliography of Fusarium (Fungi: Hyphomycetes) in South Africa, 1945-1985. Bothalia. 1985;1:97-104.

39. Doohan FM, Brennan J, Cooke BM. Influence of climatic factors on Fusarium species pathogenic to cereals. Eur J Plant Pathol. 2003;109(7):755-768. http://dx.doi.org/10.1023/A:1026090626994

40. Marasas WFO, Kriek NPJ, Wiggins VM, Steyn PS, Towers DK, Hastie TJ. Incidence, geographic distribution, and toxigenicity of Fusarium species in South African corn. Phytopathology. 1979;69:1181-1185. http://dx.doi. org/10.1094/Phyto-69-1181

41. MarasasWFO, NelsonPE, Toussoun TA, VanWykPS. Fusariumpolyphialidicum, a new species from South Africa. Mycologia. 1986;78(4):678-682.

42. Leslie JF, Summerell BA, Bullock S, Doe FJ. Description of Gibberella sacchari and neotypification of its anamorph Fusarium sacchari. Mycologia. 2005;97(3):718-724. http://dx.doi.org/10.3852/mycologia.97.3.718

43. Busman M, Desjardins AE, Proctor RH. Analysis of fumonisin contamination and the presence of Fusarium in wheat with kernel black point disease in the United States. Food Addit Contam A. 2012;29(7):1092-1100. http://dx.doi. org/10.1080/19440049.2012.671787

44. South African Grain Laboratory. South African wheat crop quality report 2013/2014 [document on the Internet]. c2014 [cited 2015 Mar 24]. Available from: http://www.sagl.co.za/Wheat/Wheatreports/20132014Season.aspx

45. Logrieco A, Mule G, Moretti A, Bottalico A. Toxigenic Fusarium species and mycotoxins associated with maize ear rot in Europe. Eur J Plant Pathol. 2002;108(7):597-609. http://dx.doi.org/10.1007/978-94-010-0001-7_1

46. Marasas WFO, Nelson PE, Toussoun TA. Toxigenic Fusarium species: Identity and mycotoxicology. Philadelphia, PA: The Pennsylvania State University Press; 1984

47. Leslie JF, Summerell BA. The Fusarium laboratory manual. Ames: Blackwell Publishing; 2006.
48. Marasas WFO. Mycotoxicological investigations on corn produced in esophageal cancer areas in Transkei. In: Pfeiffer CJ. Cancer of the esophagus. Boca Raton, FL: CRC Press; 1982. p. 29-40.

49. Chilaka CA. A survey of South African commercial feed grade maize for mycotoxins with particular reference to fumonisins using different analytical techniques [MTech thesis]. Johannesburg: University of Johannesburg; 2012.

50. Patience JF, Ensley SM, Hoyer S. Mycotoxin contamination of corn: What it is, what it does to pigs and what can be done about it. lowa Pork Industry Center Fact Sheets Paper 18 [document on the Internet]. c2010 [cited 2016 Jan 23]. Available from: http://lib.dr.iastate.edu/cgi/viewcontent. cgi?article $=1017 \&$ context $=$ ipic_factsheets

51. Matny ON. Screening of mycotoxin produced by Fusarium verticillioides and F. proliferatum in culture media. Asian J Agric Rural Dev. 2014;4(1):36-41.

52. Rabie CJ, Lübben A. The mycoflora of sorghum: Sorghum caffrorum malt. S Afr J Bot. 1984;3:251-255

53. Marasas WFO, Rabie CJ, Lübben A, Nelson PE, Toussoun TA, Van Wyk PS Fusarium nygamai from millet in southern Africa. Mycologia. 1988;80(2):263266. http://dx.doi.org/10.2307/3807807

54. Herebian D, Zuhlke S, Lamshoft M, Spiteller M. Multi-mycotoxin analysis in complex biological matrices using LC-ESI/MS: Experimental study using triple stage quadrupole and LTQ-Orbitrap. J Sep Sci. 2009;32:939-948. http:// dx.doi.org/10.1002/jssc.200800589

55. Wolf JC, Mirocha CJ. Regulation of sexual reproduction in Gibberella zeae (Fusarium roseum 'Graminearum') by F-2 (zearalenone). Can J Microbiol. 1973;19(6):725-734. http://dx.doi.org/10.1139/m73-117

56. Mesterhazy A. Role of deoxynivalenol in aggressiveness of Fusarium graminearum and $F$. culmorum and in resistance to Fusarium head blight. Eur J Plant Pathol. 2002;108(7):675-684. http://dx.doi. org/10.1023/A:1020631114063

57. Proctor RH, Hohn TM, McCormick SP. Reduced virulence of Gibberella zeae caused by disruption of a trichothecene toxin biosynthetic gene. Mol Plant Microbe Interact. 1995;8(4):593-601. http://dx.doi.org/10.1094/MPMI-80593

58. Harris LJ, Desjardins AE, Plattner RD, Nicholson P, Butler B, Young JC, et al. Possible role of trichothecene mycotoxins in virulence of Fusarium graminearum on maize. Plant Dis. 1999;83(10):954-960. http://dx.doi. org/10.1094/PDIS.1999.83.10.954

59. Proctor RH, Desjardins AE, McCormick SP, Plattner RD, Alexander NJ, Brown DW. Genetic analysis of the role of trichothecene and fumonisin mycotoxins in the virulence of Fusarium. Eur J Plant Pathol. 2002;108(7):691-698. http:// dx.doi.org/10.1023/A:1020637832371

60. Adams GC, Hart LP. The role of deoxynivalenol and 15-acetyldeoxynivalenol in pathogenesis by Gibberella zeae, as elucidated through protoplast fusions between toxigenic and nontoxigenic strains. Phytopathology. 1989;79:404408. http://dx.doi.org/10.1094/Phyto-79-404

61. Williams LD, Glenn AE, Zimeri AM, Bacon CW, Smith MA, Riley RT. Fumonisin disruption of ceramide biosynthesis in maize roots and the effects on plant development and Fusarium verticillioides-induced seedling disease. J Agric Food Chem. 2007;55(8):2937-2946. http://dx.doi.org/10.1021/jf0635614

62. Arias SL, Theumer MG, Mary VS, Rubinstein HR. Fumonisins: Probable role as effectors in the complex interaction of susceptible and resistant maize hybrids and Fusarium verticillioides. J Agric Food Chem. 2012;60(22):56675675. http://dx.doi.org/10.1021/jf3016333

63. Van Asch MAJ, Rijkenberg FHJ, Coutinho TA. Phytotoxicity of fumonisin B1, moniliformin, and T-2 toxin to corn callus cultures. Phytopathology. 1992;82:1330-1332. http://dx.doi.org/10.1094/Phyto-82-1330

64. Glenn AE, Zitomer NC, Zimeri AM, Williams LD, Riley RT, Proctor RH. Transformation-mediated complementation of a FUM gene cluster deletion in Fusarium verticillioides restores both fumonisin production and pathogenicity on maize seedlings. Mol Plant Microbe Interact. 2008;21(1):87-97. http:// dx.doi.org/10.1094/MPMI-21-1-0087

65. Desjardins AE, Plattner RD, Nelsen TC, Leslie JF. Genetic analysis of fumonisin production and virulence of Gibberella fujikuroi mating population A (Fusarium moniliforme) on maize (Zea mays) seedlings. Appl Environ Microbiol. 1995;61(1):79-86. 
66. Shim W-B, Woloshuk CP. Regulation of fumonisin B1 biosynthesis and conidiation in Fusarium verticillioides by a cyclin-like (C-type) gene, FCC1. Appl Environ Microbiol. 2001;67(4):1607-1612. http://dx.doi.org/10.1128/ AEM.67.4.1607-1612.2001

67. Keyser Z, Vismer HF, Klaasen JA, Snijman PW, Marasas WFO. The antifungal effect of fumonisin B1 on Fusarium and other fungal species. S Afr J Sci. 1999;95(10):455-458.

68. Vesonder RF, Ciegler A, Jensen AH, Rohwedder WK, Weisleder D. Co-identity of the refusal and emetic principle from Fusarium-infected corn. Appl Environ Microbiol. 1976;31(2):280-285

69. Young LG, McGirr L, Valli VE, Lumsden JH, Lun A. Vomitoxin in corn fed to young pigs. J Anim Sci. 1983;57(3):655-664.

70. Bergsjø B, Matre T, Nafstad I. Effects of diets with graded levels of deoxynivalenol on performance in growing pigs. J Vet Med. 1992;39(110):752-758. http://dx.doi.org/10.1111/j.1439-0442.1992.tb00240.x

71. Pestka JJ. Deoxynivalenol: Toxicity, mechanisms and animal health risks. Anim Feed Sci Technol. 2007;137(3):283-298. http://dx.doi.org/10.1016/j. anifeedsci.2007.06.006

72. Yoshizawa T, Morooka N. Acute toxicities of the new trichothecene mycotoxins: Deoxynivalenol and its monoacetate. J Food Hyg Soc Japan. 1974;15:261-269.

73. European Union. Commission regulation (EC) no 1881/2006 of 19 December 2006, as amended, on setting maximum levels for certain contaminants in foodstuffs [document on the Internet]. c2006 [cited 2015 Mar 31]. Available from: http://eur-lex.europa.eu/legal-content/EN/TXT/PDF/?uri=CELEX:32006 $\mathrm{R} 1881 \&$ from $=\mathrm{EN}$

74. Hamilton PB. Factors influencing activity of fungi and antifungal agents in poultry feed. In: Trichothecenes and other mycotoxins. New York: John Wiley and Sons; 1985. p. 207-218.

75. Hedman R, Pettersson H, Engström B, Elwinger K. Fossum O. Effects of feeding nivalenol-contaminated diets to male broiler chickens. Poultry Sci. 1995;74(4):620-625

76. Marasas WFO, Kellerman TS, Gelderblom WCA, Coetzer JAW, Thiel PG, Van der Lugt JJ. Leukoencephalomalacia in a horse induced by fumonisin B1, isolated from Fusarium moniliforme. Onderstepoort J Vet Res. 1988;55(4):197-203.

77. Kellerman TS, Marasas WFO, Thiel PG, Gelderblom WC, Cawood M, Coetzer JA. Leukoencephalomalacia in two horses induced by oral dosing of fumonisin B1. Onderstepoort J Vet Res 1990;57(4):269-275.

78. Bucci T, Hansen DK, LaBorde JB. Leucoencephalomalacia and hemorrhage in the brain of rabbits gavaged with mycotoxin fumonisins B1. Nat Toxins. 1996;4(1):51-52.

79. Colvin BM, Harrison LR. Fumonisin-induced pulmonary edema and hydrothorax in swine. Mycopathologia. 1992;117(1-2):79-82.

80. Gelderblom WCA, Jaskiewicz K, Marasas WFO, Thiel PG, Horak RM, Vleggaar $\mathrm{R}$, etal. Fumonisins: Novel mycotoxins with cancer promoting activity produced by Fusarium moniliforme. Appl Environ Microbiol. 1988;54(7):1806-1811.

81. Gelderblom WCA, Jaskiewicz K, Marasas WFO, Thiel PG. Toxicity and carcinogenicity of the Fusarium moniliforme metabolite, fumonisin B1 in rats. Carcinogenesis. 1991;12(7):1247-1251. http://dx.doi.org/10.1093/ carcin/12.7.1247

82. Rheeder JP, Marasas WFO, Thiel PG, Sydenham EW, Shephard GS, Van Schalkwyk DJ. Fusarium moniliforme and fumonisins in corn in relation to human esophageal cancer in Transkei. Phytopathology. 1992;82:353-357. http://dx.doi.org/10.1094/Phyto-82-353

83. Marasas WFO. Occurrence of Fusarium moniliforme and fumonisins in maize in relation to human health. S Afr Med J. 1993;83(6):382-383.

84. World Health Organization (WHO). Safety evaluation of certain mycotoxins in food. Geneva: WHO; 2001.

85. Williams JH, Grubb JA, Davis JW, Wang JS, Jolly PE, Ankrah NA, et al. HIV and hepatocellular and esophageal carcinomas related to consumption of mycotoxin-prone foods in sub-Saharan Africa. Am J Clin Nutr. 2010;92(1):154-160. http://dx.doi.org/10.3945/ajcn.2009.28761

86. Kuiper-Goodman T, Scott PM, Watanabe H. Risk assessment of the mycotoxin zearalenone. Regul Toxicol Pharmacol. 1987;7(3):253-306.
87. Stob J, Baldwin RS, Tuite J, Andrews FN, Gillette KG. Isolation of an anabolic uterotrophic compound form corn infected with Gibberella zeae. Nature. 1962;196:1318-1318.

88. Allen NK, Mirocha CJ, Aakus-Allen S, Bitgood JJ, Weaver G, Bates F. Effect of dietary zearalenone on reproduction of chickens. Poultry Sci. 1981;60(6):1165-1174.

89. Allen NK, Peguri A, Mirocha CJ, Newman JA. Effects of Fusarium cultures, T-2 toxin and zearalenone on reproduction of turkey females. Poultry Sci. 1983;62(2):282-289

90. Zinedine A, Soriano JM, Moltó JC, Mañes J. Review on the toxicity, occurrence, metabolism, detoxification, regulations and intake of zearalenone: An oestrogenic mycotoxin. Food Chem Toxicol. 2007;45(1):1-18. http://dx.doi. org/10.1016/j.fct.2006.07.030

91. Massart F, Meucci V, Saggese G, Soldani G. High growth rate of girls with precocious puberty exposed to estrogenic mycotoxins. J Pediatr. 2008;152(5):690-695. http://dx.doi.org/10.1016/j.jpeds.2007.10.020

92. Ahamed S, Foster JS, Bukovsky A, Wimalasena J. Signal transduction through the ras/Erk pathway is essential for the mycoestrogen zearalenone-induced cell-cycle progression in MCF-7 cells. Mol Carcinog. 2001;30(2):88-98.

93. Food and Drug Administration (FDA). Guidance for industry and FDA: Advisory levels for deoxynivalenol (DON) in finished wheat products for human consumption and grains and grain by-products used for animal feed [document on the Internet]. c2010 [cited 2015 Mar 31]. Available from: http://www.fda. gov/Food/GuidanceRegulation/GuidanceDocumentsRegulatoryInformation/ ucm120184.htm

94. Food and Agriculture Organization of the United Nations (FAO). Worldwide regulations for mycotoxins in food and feed in 2003 [document on the Internet]. c2004 [cited 2015 Mar 31]. Available from http://www.fao.org/ docrep/007/y5499e/y5499e00.htm

95. Magan N, Olsen M. Mycotoxins in food: Detection and control. Abington: Woodhead Publishing Limited; 2004.

96. CAC/RCP 1-1969 Revision 4: Recommended international code of practice general principles of food hygiene [document on the Internet]. c2003 [cited 2015 Mar 28]. Available from: http://www.mhlw.go.jp/english/topics/ importedfoods/guideline/dl/04.pdf

97. Blandino M, Pilati A, Reyneri A, Scudellari D. Effect of maize crop residue density on Fusarium head blight and on deoxynivalenol contamination of common wheat grains. Cereal Res Commun. 2010;38(4):550-559. http:// dx.doi.org/10.1556/CRC.38.2010.4.12

98. Gilbert J, Tekauz A. Strategies for management of Fusarium head blight (FHB) in cereals. Prairie Soils Crops J. 2011;4:97-104.

99. McMullen M, Lukach J, McKay K, Schatz B. Fungicide and biological agent effects on Fusarium head blight across two wheat classes. J Appl Genet. 2002;43A:223-226.

100. Munkvold GP. Cultural and genetic approaches to managing mycotoxins in maize. Annu Rev Phytopathol. 2003;41:99-116. http://dx.doi.org/10.1146/ annurev.phyto.41.052002.095510

101. Parsons MW, Munkvold GP. Associations of planting date, drought stress, and insects with Fusarium ear rot and fumonisin B1 contamination in California maize. Food Addit Contam A. 2010;27(5):591-607. http://dx.doi. org/10.1080/19440040903456337

102. Dutton MF, Westlake K. Occurrence of mycotoxins in cereals and animal feedstuffs in Natal, South Africa. J Assoc Off Anal Chem. 1985;68(5):839842.

103. Ferreira MI, Reinhardt CG, Lamprecht SC, Sinclair M, MacKenzie L, Van Coller GJ. Morphological identification of the ryegrass hybrid Lolium multiflorum $\times$ Lolium perenne and isolation of the pathogen Fusarium pseudograminearum in the Western Cape. S Afr J Plant Soil. 2015;32(1):9-15.

104. Van Zyl K. The control of fungal, viral and bacterial diseases in plants. Johannesburg: Association of Veterinary and Crop Associations of South Africa; 2011.

105. Edwards SG, Pirgozliev SR, Hare MC, Jenkinson P. Quantification of trichothecene-producing Fusarium species in harvested grain by competitive PCR to determine the efficacy of fungicides against Fusarium head blight of winter wheat. Appl Environ Microbiol. 2001;67(4):1575-1580. http://dx.doi. org/10.1128/AEM.67.4.1575-1580.2001 
106. Janse van Rensburg B, McLaren NW, Flett BC, Schoeman A. The effects of cultivar and prophylactic fungicide spray for leaf diseases on colonisation of maize ears by fumonisin producing Fusarium spp. and fumonisin synthesis in South Africa. Crop Prot. 2015;79:56-63. http://dx.doi.org/10.1016/j. cropro.2015.10.009

107. Small IM, Flett BC, Marasas WFO, McLeod A, Viljoen A. Use of resistance elicitors to reduce Fusarium ear rot and fumonisin accumulation in maize. Crop Prot. 2012;41:10-16. http://dx.doi.org/10.1016/j.cropro.2012.05.016

108. Pal KK, McSpadden-Gardener B. Biological control of plant pathogens. The Plant Health Instructor. 2006; 25 pages. http://dx.doi.org/10.1094/ PHI-A-2006-1117-02

109. Schisler DA, Khan NI, Boehm MJ. Biological control of Fusarium head blight of wheat and deoxynivalenol levels in grain via use of microbial antagonists. Adv Exp Med Biol. 2002;504:53-69.

110. Diamond H, Cooke B. Preliminary studies on biological control of Fusarium ear blight complex of wheat. Crop Prot. 2003;22:99-107. http://dx.doi. org/10.1016/S0261-2194(02)00117-5

111. Idris HA, Labuschagne N, Korsten L. Screening rhizobacteria for biological control of Fusarium root and crown rot of sorghum in Ethiopia [document on the Internet]. c2007 [cited 2015 Mar 30]. Available from: http:// repository.up.ac.za/bitstream/handle/2263/3201/Idris_Screening(2007). pdf?sequence $=1$

112. McCartney CA, Somers DJ, Fedak G, DePauw RM, Thomas J, Fox SL, et al. The evaluation of FHB resistance QTLs introgressed into elite Canadian spring wheat germplasm. Mol Breeding. 2007;20(3):209-221. http://dx.doi. org/10.1007/s11032-007-9084-Z

113. Yu JB, Bai GH, Cai SB, Ban T. Marker-assisted characterization of Asian wheat lines for resistance to Fusarium head blight. Theor Appl Genet. 2006;113(2):308-320. http://dx.doi.org/10.1007/s00122-006-0297-z

114. Collard BCY, Jahufer MZZ, Brouwer JB, Pang ECK. An introduction to markers, quantitative trait loci (QTL) mapping and marker-assisted selection for crop improvement: The basic concepts. Euphytica. 2005;142(1):169-196. http:// dx.doi.org/10.1007/s10681-005-1681-5

115. Van Coller GJ, Lamprecht SC, Viljoen A. Resistance of South African wheat cultivars and test lines to Fusarium head blight caused by F. graminearum s.s. and F. pseudograminearum. In: 49th Congress of the Southern African Society for Plant Pathology; 2015 January 18-23; Bloemfontein, South Africa. Available from: http://www.saspp.co.za/forms/SASPP-2015-abstracts.pdf

116. Small IM, Flett BC, Marasas WFO, McLeod A, Stander MA, Viljoen A. Resistance in maize inbred lines to Fusarium verticillioides and fumonisin accumulation in South Africa. Plant Dis. 2012;96(6):881-888. http://dx.doi. org/10.1094/PDIS-08-11-0695

117. Robertson-Hoyt LA, Jines MP, Balint-Kurti PJ, Kleinschmidt CE, White DG, Payne GA, etal. QTL mapping for Fusarium ear rot and fumonisin contamination resistance in two maize populations. Crop Sci. 2006;46(4):1734-1743. http://dx.doi.org/10.2135/cropsci2005.12-0450

118. Ding J-Q, Wang X, Chander S, Yan J, Li J. QTL mapping of resistance to Fusarium ear rot using a RIL population in maize. Mol Breed. 2008;22(3):395403. http://dx.doi.org/10.1007/s11032-008-9184-4

119. Rami JF, Dufour P, Trouche G, Fliedel G, Mestres C, Davrieux F, et al. Quantitative trait loci for grain quality, productivity, morphological and agronomical traits in sorghum (Sorghum bicolor (L.) Moench). Theor Appl Genet. 1998;97(4):605-616. http://dx.doi.org/10.1007/s001220050936

120. Rooney WL, Klein RR. Potential of marker assisted selection for improving grain mold resistance in sorghum. In: Chandrashekar A, Bandyopadhyay R, Hall AL, editors. Technical and institutional options for sorghum grain mold management: Proceedings of an international consultation; 2000 May 18-19; Patancheru, India. Patancheru: ICRISAT; 2000. p. 183-194.

121. Mace ES, Xia L, Jordan DR, Halloran K, Parh DK, Huttner E, et al. DArT markers: Diversity analyses and mapping in Sorghum bicolor. BMC Genomics. 2008;9:26. http://dx.doi.org/10.1186/1471-2164-9-26

122. Munkvold GP, Hellmich RL, Rice LG. Comparison of fumonisin concentrations in kernels of transgenic Bt maize hybrids and nontransgenic hybrids. Plant Dis. 1999;83(2):130-138. http://dx.doi.org/10.1094/PDIS.1999.83.2.130
123. Duvick J, Rood T, Maddox JR, Wang X. Fumonisin detoxification compositions and methods. United States Patent US5792931 [online]. c1998 [cited 2015 Mar 28]. Available from: http://www.google.com/patents/ US5792931\#forward-citations

124. Munkvold GP, Desjardins AE. Fumonisins in maize: Can we reduce their occurrence? Plant Dis. 1997;81(6):556-565. http://dx.doi.org/10.1094/ PDIS.1997.81.6.556

125. Ono EYS, Sasaki EY, Hashimoto EH, Hara LN, Correa B, Itano EN, et al. Postharvest storage of corn: Effect of beginning moisture content on mycoflora and fumonisin contamination. Food Addit Contam. 2002:19(11):1081-1090. http://dx.doi.org/10.1080/02652030210146828

126. Richard JL. Some major mycotoxins and their mycotoxicoses - An overview. Int J Food Microbiol. 2007;119(1-2):3-10. http://dx.doi.org/10.1016/j. ijfoodmicro.2007.07.019

127. Sydenham EW, Van der Westhuizen L, Stockenström S, Shephard GS, Thiel PG. Fumonisin-contaminated maize: Physical treatment for the partial decontamination of bulk shipments. Food Addit Contam. 1994;11(1):25-32.

128. Mogensen JM, Sørensen SM, Sulyok M, Van der Westhuizen L, Shephard GS, Frisvad JC, et al. Single kernel analysis of fumonisins and other fungal metabolites in maize from South African subsistence farmers. Food Addit Contam. 2011;28(12):1724-1734. http://dx.doi.org/10.1080/19440049.20 11.611823

129. Shetty PH, Bhat RV. A physical method for segregation of fumonisincontaminated maize. Food Chem. 1999;66(3):371-374. http://dx.doi. org/10.1016/S0308-8146(99)00052-7

130. Abbas HK, Mirocha CJ, Pawlosky RJ, Pusch DJ. Effect of cleaning, milling, and baking on deoxynivalenol in wheat. Appl Environ Microbiol. 1985;50(2):482-486.

131. Shephard GS, Leggott NL, Stockenström S, Somdyala NIM, Marasas WFO. Preparation of South African maize porridge: Effect on fumonisin mycotoxin levels. S Afr J Sci. 2002;98(7/8):393-396.

132. Trenholm HL, Charmley LL, Prelusky DB, Warner RM. Washing procedures using water or sodium carbonate solutions for the decontamination of three cereals contaminated with deoxynivalenol and zearalenone. J Agric Food Chem. 1992;40(11):2147-2151. http://dx.doi.org/10.1021/jf00023a021

133. Young JC, Subryan LM, Potts D, McLaren ME, Gobran FH. Reduction in levels of deoxynivalenol in contaminated wheat by chemical and physical treatment J Agric Food Chem. 1986;34(3):461-465.

134. Young JC, Zhu H, Zhou T. Degradation of trichothecene mycotoxins by aqueous ozone. Food Chem Toxicol. 2006;44(3):417-424. http://dx.doi. org/10.1016/j.fct.2005.08.015

135. Abramson D, House JD, Nyachoti CM. Reduction of deoxynivalenol in barley by treatment with aqueous sodium carbonate and heat. Mycopathologia. 2005;160(4):297-301. http://dx.doi.org/10.1007/s11046-005-0087-1

136. Wilson SC, Brasel TL, Martin JM, Wu C, Andriychuk L, Douglas DR, et al. Efficacy of chlorine dioxide as a gas and in solution in the inactivation of two trichothecene mycotoxins. Int J Toxicol. 2005;24(3):181-186. http://dx.doi. org/10.1080/10915810590953437

137. Karlovsky P. Biological detoxification of the mycotoxin deoxynivalenol and its use in genetically engineered crops and feed additives. Appl Microbiol Biotechnol. 2011;91(3):491-504. http://dx.doi.org/10.1007/s00253-011-3401-5

138. Karlovsky P. Biological detoxification of fungal toxins and its use in plant breeding, feed and food production. Nat Toxins. 1999;7(1):1-23. http://dx.doi. org/10.1002/(SICI)1522-7189(199902)7:1<1::AID-NT37>3.0.C0;2-9

139. Rheeder JP, Shephard GS, Vismer HF, Gelderblom WCA. Medical Research Council (MRC) policy brief. Guidelines on mycotoxin control in South African foodstuffs: From the application of the Hazard Analysis and Critical Control Point (HACCP) system to new national mycotoxin regulations [document on the Internet]. c2009 [cited 2015 Aug 18]. Available from: http://www.mrc. ac.za/policybriefs/Mycotoxinguidelines.pdf

140. Rabie CJ, Marasas WFO, Thiel PG, Lübben A, Vleggaar R. Moniliformin production and toxicity of different Fusarium species from southern Africa. Appl Environ Microbiol. 1982;43(3):517-521.

141. Rabie CJ, Sydenham EW, Thiel PG, Lübben A, Marasas WFO. T-2 toxin production by Fusarium acuminatum isolated from oats and barley. Appl Environ Microbiol. 1986;52(3):594-596. 
142. Logrieco A, Moretti A, Castella G, Kostecki M, Golinski P, Ritieni A, et al. Beauvericin production by Fusarium species. Appl Environ Microbiol. 1998;64(8):3084-3088

143. Marín P, Moretti A, Ritieni A, Jurado M, Vázquez CM, González-Jaén T Phylogenetic analyses and toxigenic profiles of Fusarium equiseti and Fusarium acuminatum isolated from cereals from southern Europe. Food Microbiol. 2012;31(2):229-237. http://dx.doi.org/10.1016/j.fm.2012.03.014

144. Hossain MT. Studies of the impact of mycoflora associated with Oryza sativa (rice) in South Africa [PhD thesis]. Pretoria: University of Pretoria; 2013.

145. Chelkowski J, Lew H. Fusarium species of Liseola Section- occurrence in cereals and ability to produce fumonisins. Microbiol Alim Nutr. 1992;10:49-53.

146. Doidge EM, Bottomley AM, Van der Planck JE, Pauer GD. A revised list of plant diseases occurring in South Africa (Science Bulletin). Pretoria: Department of Agriculture; 1953.

147. Abbas HK, Mirocha CJ, Gunther R. Mycotoxins produced by toxic Fusarium isolates obtained from agricultural and nonagricultural Arctic areas of Norway. Mycopathologia. 1989;105(3):143-151. http://dx.doi.org/10.1007/ BF00437246

148. Kokkonen M, Ojala L, Parikka P, Jestoi M. Mycotoxin production of selected Fusarium species at different culture conditions. Int J Food Microbiol. 2010;143(1-2):17-25. http://dx.doi.org/10.1016/j.ijfoodmicro.2010.07.015

149. Tan DC, Flematti GR, Ghisalberti EL, Sivasithamparam K, Chakraborty $\mathrm{S}$, Obanor $\mathrm{F}$, et al. Mycotoxins produced by Fusarium species associated with annual legume pastures and 'sheep feed refusal disorders' in Western Australia. Mycotoxin Res. 2011;27(2):123-135. http://dx.doi.org/10.1007/ s12550-010-0085-0

150. Di Menna ME, Lauren DR, Smith WA. An effect of incubation temperature on zearalenone production by strains of Fusarium crookwellense. Mycopathologia. 1991;116(2):81-86. http://dx.doi.org/10.1007/BF00436369

151. Vermeulen M, Swart WJ, Gryzenhout M. Fusarium species associated with decayed and healthy tissue of Amaranthus cruentus and three weevil species in South Africa. In: 49th Congress of the Southern African Society for Plant Pathology; 2015 January 18-23; Bloemfontein, South Africa. Available from: http://www.saspp.co.za/forms/SASPP-2015-abstracts

152. Park J, Chu FS. Immunochemical analysis of trichothecenes produced by various fusaria. Mycopathologia.1993;121(3):179-192. http://dx.doi. org/10.1007/BF01104075

153. Greenhalgh R, Levandier D, Adams W, Miller JD, Blackwell BA, McAlees AJ, et al. Production and characterization of deoxynivalenol and other secondary metabolites of Fusarium culmorum. J Agric Food Chem. 1986;34(1):98-102.

154. Scott PM, Abbas HK, Mirocha CJ, Lawrence GA, Weber D. Formation of moniliformin by Fusarium sporotrichioides and Fusarium culmorum. Appl Environ Microbiol. 1987;53(1):196-197.

155. Matny ON. Detection of deoxynivalenol, zearalenone and T2-toxin produced by Fusarium species in different cultures. Int J Agric Crop Sci. 2013;5(20):2385-2389. Available from: http://ijagcs.com/wp-content/ uploads/2013/09/2385-23891.pdf

156. SchüttF, Nirenberg HI, DemI G. Moniliformin production in the genus Fusarium. Mycotoxin Res. 1998;14(1):35-40. http://dx.doi.org/10.1007/BF02945091

157. Rheeder JP, Marasas WFO, Nelson PE. Fusarium globosum, a new species from corn in southern Africa. Mycologia. 1996;88(3):509-513. http://dx.doi. org/10.2307/3760891

158. Sydenham EW, Shephard GS, Stockenström S, Rheeder JP, Marasas WFO, Van der Merwe MJ. Production of fumonisin B analogues and related compounds by Fusarium globosum, a newly described species from corn. J Agric Food Chem. 1997;45(10):4004-4010. http://dx.doi.org/10.1021/jf9607066

159. Shephard GS, Sewram V, Nieuwoudt TW, Marasas WFO, Ritieni A. Production of the mycotoxins fusaproliferin and beauvericin by South African isolates in the Fusarium section Liseola. J Agric Food Chem. 1999;47(12):5111-5115. http://dx.doi.org/10.1021/jf9903713

160. Moss MO, Thrane H. Fusarium taxonomy with relation to trichothecene formation. Toxicol Lett. 2004;153(1):23-28. http://dx.doi.org/10.1016/j. toxlet.2004.04.021
161. De Saeger S. Determining mycotoxins and mycotoxigenic fungi in food and feed. Amsterdam: Elsevier; 2011.

162. Nelson PE, Plattner RD, Shackelford DD, Desjardins AE. Fumonisin B1 production by Fusarium species other than F. moniliforme in Section Liseola and by some related species. Appl Environ Microbiol. 1992;58(3):984-989.

163. Magnoli CE, Saenz MA, Chiacchiera SM, Dalcero AM. Natural occurrence of Fusarium species and fumonisin-production by toxigenic strains from poultry feeds in Argentina. Mycopathologia. 1999;145(1):35-41. http://dx.doi. org/10.1023/A:1007053617961

164. Du Toit JJ. Root rot of young maize plants - The causal fungi. S Afr J Agric Sci. 1968;11:595-604

165. Abbas HK, Ocamb CM, Xie W, Mirocha CJ, Shier WT. First report of fumonisin B1, B2 and B3 production by Fusarium oxysporum var. redolens. Plant Dis. 1995;79(6):968. http://dx.doi.org/10.1094/PD-79-0968C

166. Beev G, Denev S, Bakalova D. Zearalenone-producing activity of Fusarium graminearum and Fusarium oxysporum isolated from Bulgarian wheat. Bulg J Agric Sci. 2013;19(2):255-259.

167. Leslie JF, Plattner RD, Desjardins AE, Klittich CJR. Fumonisin B1 production by strains from different mating populations of Gibberella fujikuroi (Fusarium Section Liseola). Phytopathology. 1992;82(3):341-345. http://dx.doi. org/10.1094/Phyto-82-341

168. Logrieco A, Moretti A, Ritieni A, Bottalico A, Corda P. Occurrence and toxigenicity of $F$. proliferatum from preharvest maize ear rot and associated mycotoxins in Italy. Plant Dis. 1995;79(7):727-731. http://dx.doi. org/10.1094/PD-79-0727

169. Ritieni A, Moretti A, Logrieco A, Bottalico A, Randazzo G, Monti SM, et al. Occurrence of fusaproliferin, fumonisin B1, and beauvericin in maize from Italy. J Agric Food Chem. 1997;45(10):4011-4016. http://dx.doi. org/10.1021/jf9702151

170. Blaney BJ, Dodman RL. Production of zearalenone, deoxynivalenol, nivalenol, and acetylated derivatives by Australian isolates of Fusarium graminearum and $F$. pseudograminearum in relation to source and culturing conditions. Aust J Agric Res. 2002;53(12):1317-1326.

171. Clear RM, Patrick SK, Gaba D, Roscoe M, Turkington TK, Demeke T, et al. Trichothecene and zearalenone production, in culture, by isolates of Fusarium pseudograminearum from western Canada. Can J Plant Pathol. 2006;28(1):131-136. http://dx.doi.org/10.1080/07060660609507279

172. Fotso J, Leslie JF, Smith JS. Production of beauvericin, moniliformin, fusaproliferin, and fumonisins B1, B2 and B3 by ex-type strains of fifteen Fusarium species. Appl Environ Microbiol. 2002;68(10):5195-5197. http:// dx.doi.org/10.1128/AEM.68.10.5195-5197.2002

173. Gupta S, Krasnoff SB, Underwood NL, Renwick JAA, Roberts DW. Isolation of beauvericin as an insect toxin from Fusarium semitectum and Fusarium moniliforme var. subglutinans. Mycopathologia. 1991;115(3):185-189. http://dx.doi.org/10.1007/BF00462223

174. Farber JM, Sanders GW, Lawrence GA, Scott PM. Production of moniliformin by Canadian isolates of Fusarium. Mycopathologia. 1988;101(3):187-190. http://dx.doi.org/10.1007/BF00437038

175. Chelkowski J, Zawadzki M, Zajkowski P, Logrieco A, Bottalico A. Moniliformin production by Fusarium species. Mycotoxin Res. 1990;6(1):41-45. http:// dx.doi.org/10.1007/BF03192137

176. Bacon CW, Porter JK, Norred WP, Leslie JF. Production of fusaric acid by Fusarium species. Appl Environ Microbiol. 1996;62(11):4039-4043.

177. Desjardins AE, Plattner RD, Gordon TR. Gibberella fujikuroi mating population A and Fusarium subglutinans from teosinte species and maize from Mexico and Central America. Mycol Res. 2000;104(7):865-872.

178. Leslie JF, Marasas WFO, Shephard GS, Sydenham EW, Stockenström S, Thie PG. Duckling toxicity and the production of fumonisin and moniliformin by isolates in the $A$ and $F$ mating populations of Gibberella fujikuroi. Appl Environ Microbiol. 1996;62(4):1182-1187.

179. Bryden WL, Logrieco A, Abbas HK, Porter JK, Vesonder RF, Richard JL, et al. Other significant Fusarium mycotoxins. In: Summerell BA, Leslie JF, Backhouse D, Bryden WL, Burgess LW, editors. Fusarium. St. Paul, MN: APS Press; 2001. p. 360-392. 
180. Schoeman A. The diversity and population structure of Fusarium verticillioides in South Africa [PhD thesis]. Stellenbosch: Stellenbosch University; 2014.

181. Scauflaire J, Gourgue M, Callebaut A, Munaut F. Fusarium temperatum, a mycotoxin-producing pathogen of maize. Eur JPlantPathol. 2012;133(4):911922. http://dx.doi.org/10.1007/s10658-012-9958-8

182. Marasas WFO, Smalley EB, Hamburg JR, Strong FM. Phytotoxicity of T-2 toxin produced by Fusarium tricinctum. Phytopathology. 1971;61(12):1488-1491.

183. Bottalico A, Logrieco A, Ritieni A, Moretti A, Randazzo G, Corda P. Beauvericin and fumonisin $B 1$ in preharvest Fusarium moniliforme maize ear rot in Sardinia. Food Addit Contam. 1995;12(4):599-607.
184. Placinta CM, D'Mello JPF, MacDonald AMC. A review of worldwide contamination of cereal grains and animal feed with Fusarium mycotoxins. Anim Feed Sci Technol. 1999;78(1-2):21-37. http://dx.doi.org/10.1016/ S0377-8401(98)00278-8

185. Aoki T, Ward TJ, Kistler HB, O'Donnell K. Systematics, phylogeny and trichothecene mycotoxin potential of Fusarium head blight cereal pathogens. Mycotoxins. 2012;62(2):91-102. http://dx.doi.org/10.2520/myco.62.91

186. South African Gazette. Foodstuffs, Cosmetics and Disinfectants Act (54/1972): Regulations governing tolerances for fungus-produced toxins in foodstuffs: Amendment [document on the Internet]. c2016 [cited 2016 Dec 07]. Available from: https://www.greengazette.co.za/documents/nationalgazette-40250-of-05-september-2016-vol-615_20160905-GGN-40250.pdf 